\title{
New sauropod trackways from the Middle Jurassic of Portugal
}

\author{
Vanda F. Santos, José J. Moratalla, and Rafael Royo-Torres \\ Acta Palaeontologica Polonica 54 (3), 2009: 409-422 doi: http://dx.doi.org/10.4202/app.2008.0049
}

The Galinha tracksite reveals a sequence of Bajocian-Bathonian limestones belonging to the Serra de Aire Formation (West-Central Portugal) and is one of the few sites in the world where Middle Jurassic sauropod dinosaur tracks can be found. This tracksite is characterised by the presence of long, wide gauge sauropod trackways, the Middle Jurassic age of which suggests these dinosaurs were more widely distributed over time than previously thought. Two trackways contain unique pes and manus prints with morphologies that allow a new sauropod ichnotaxon to be described: Polyonyx gomesi igen. et isp. nov. On the basis of different manus/pes prints and trackway features, the proposal is made to subdivide Sauropodomorpha ichno-morphotypes into five groups: Tetrasauropus-like, Otozoum -like, Breviparopus/Parabrontopodus-like; Brontopodus-like, and Polyonyx-like. Polyonyx gomesi igen. et isp. nov. is thought to represent a nonneosauropod eusauropod, with a well developed manus digit I. The posterior orientation of this digit print suggests they were made by a eusauropod dinosaur with a posteriorly rotated pollex. The manus print morphologies observed in two trackways suggest a stage of manus structure intermediate between the primitive non-tubular sauropod manus and the tubular metacarpal arrangement characteristic of more derived sauropods. The low heteropody (manus:pes area ratio 1:2) of the trackway renders it possible they could have been made by eusauropods such as Turiasaurus riodevensis, which has a similar manus:pes area ratio. The Polyonyx igen. nov. trackway was made by non-neosauropod eusauropod, and suggests that wide gauge sauropod trackways were not exclusively made by Titanosauriformes.

Key words: Dinosaur, Sauropoda, trackways, ichno-morphotypes, Middle Jurassic, Portugal.

Vanda Faria dos Santos [vsantos@museus.ul.pt], Museu Nacional de História Natural da Universidade de Lisboa, R. Escola Politécnica, 58, 1250-102 Lisbon, Portugal. J. Joaquín Moratalla [j.moratalla@igme.es], Instituto Geológico y Minero de España, C/ Rios Rosas, 23, 28003 Madrid, Spain. Rafael Royo-Torres [royo@ dinopolis.com], Fundación Conjunto Paleontológico de Teruel-Dinópolis, Av. Sagunto s/n, 44003 Teruel, Spain. 
This is an open-access article distributed under the terms of the Creative Commons

Attribution License (for details please see creativecommons.org), which permits unrestricted use, distribution, and reproduction in any medium, provided the original author and source are credited.

FoF 